\title{
第10回科学技術奨励金贈呈審查報告
}

科学技術奨励金委員会

委員長 山 㟝 正 宏

日本ゴム協会では科学技術奨励金に関して，日本ゴム協会誌第 69 巻 9 〜 11号に会告し，締切 の平成 8 年11月 30 日までに 3 件の申請があり, 平成 9 年 1 月 27 日（月）委員会を開催し審查の 上, 3 月17日（月）開催の理事会に推麃し, これを決定した。

\section{研究調查題目 新「ゴム用語辞典」の出版}

研 究 者 出版企画委員会

佐々木 康順 他17名

\section{推薦理由}

(1)新「ゴム用語辞典」の出版は本来ゴム協会の事業として独立すべきであるが，会員外の執 筆者を含む多くの外部協力を得て完成しつつあり, その内容も広く社会のゴム技術の普及に 役立ち，科学技術の調査研究集団としてみなすことができる.

(2)内容はゴム産業にかかわる技術者，ユーザーなど広範囲の人に役立ち，ゴム技術の普及，ゴ ム協会のレベルを対外に誇示しうるものである.

(3)現在の経済状況からみて, 本奨励金の援助がないと出版に支障を来す恐れがある.

ただし「本来は出版事業の中でまかなうべきであるが上記理由により，今回特例として認め たい」旨の意見を付し選定した。 